\title{
АКЦЕНТУАЦІї ХАРАКТЕРУ УЧНІВ ТА СТУДЕНТІВ СУЧАСНИХ НАВЧАЛЬНИХ ЗАКЛАДІВ РІЗНИХ ТИПІВ У КОНТЕКСТІ СТРЕСОСТІЙКОСТІ
}

\author{
Кандидат медичних наук, доцент Оксана Тимощук, \\ кандидат медичних наук, дочент Володимир Дерпак, \\ кандидат медичних наук, доцент Михайло Йонда, \\ асистент Токар Ірина Тадеївна, \\ асистент Кича Ірина Іванівна,
}

Украӥна, Івано-Франківськ, івано-Франківський національний медичний університет; Кафедра гігієни та екологї

DOI: https://doi.org/10.31435/rsglobal_wos/30042019/6446

\section{ARTICLE INFO}

Received: 16 February 2019

Accepted: 14 April 2019

Published: 30 April 2019

\section{KEYWORDS}

accentuations of character, stress resistance,

stress,

students,

methods by G.Shmishek.

\begin{abstract}
This work shows relevance of research into stress resistance of students at modern educational establishments. It describes methods of studying personality accentuations by G. Shmishek, examines peculiarities of stress resistance, accentuations of character and the way they affect young people. It was established that the highest values of the indicators are found in boys and girls hyperthymic type, and the lowest ones are among both the young males and females of the dysthymic type. The gender and age diversities were observed in the following accentuations: cycloid type, demonstrative type, affective-exalted, anxious, emotive, excitable. Moreover, the values of the indicators were in all groups higher for girls than for boys. The work demonstrates that each person has a certain set of features which under certain conditions can be accentuated and determine significantly the human reaction. These qualities are especially vivid in adolescence due to the imperfection and vulnerability of the nervous system, the formation of character, the change of values, selectivity and vulnerability in relation to the environment, parents and friends. Therefore, the development of ways to correct accentuated character traits among students of modern educational institutions of different types is becoming relevant.
\end{abstract}

Citation: Тимощук О., Дерпак В., Йонда М., Токар I. Т., Кича I. I. (2019) Aktsentuatsii Kharakteru Uchniv ta Studentiv Suchasnykh Navchalnykh Zakladiv Riznykh Typiv u Konteksti Stresostiikosti. International Academy Journal Web of Scholar. 4(34). doi: 10.31435/rsglobal_wos/30042019/6446

Copyright: (C 2019 Тимощук О., Дерпак В., Йонда М., Токар I. Т., Кича I. I. This is an open-access article distributed under the terms of the Creative Commons Attribution License (CC BY). The use, distribution or reproduction in other forums is permitted, provided the original author(s) or licensor are credited and that the original publication in this journal is cited, in accordance with accepted academic practice. No use, distribution or reproduction is permitted which does not comply with these terms.

Вступ. Особливості характеру людини мають важливе значення у розвитку базових параметрів поведінкових реакцій $[4,11,21]$. Термін «акцентуація» вперше запропонував німецький психіатр і психолог К. Леонгард, на думку якого акцентуація - це індивідуальні особливості особистості наближені до патологічного стану $[18,20,23]$. Акцентуйовані особи - це не хворі, а цілком здорові особистості із деякими індивідуальними особливостями, в яких генетично закладені перспективи як до соціально позитивних, так і до соціально негативних досягнень. У людей з акцентуйованим типом характеру поведінка дещо відрізняється від основної більшості і в деяких життєвих ситуаціях це іiі сила, а в деяких - слабкість $[2,7,15]$. Базовим елементом акцентуації $\epsilon$ природна здатність людини, а формування акцентуйованого характеру в загальному залежить від виховання особистості та соціального середовища ії перебування $[1,9,12]$. 
Порушення поведінки підлітків у сучасному середовищі $є$ дуже актуальною проблемою, оскільки соціальні аспекти активного розвитку суспільства ставлять більш високі вимоги до нервової системи підлітка, ніж, наприклад, півстоліття тому, і в результаті цього виникають часті нервові зриви та девіантна поведінка серед юнаків та дівчат $[6,10]$. У ході становлення особистості відбуваються негативні зміни в характері учнів та студентів, які можуть впливати на цілісність особистості, знижуючи властивості адаптаційних процесів та впливаючи на продуктивність життєдіяльності і розглядаються як акцентуації рис характеру, які розвиваються під дією нервової системи, характерних особливостей виховання в родині, соціального середовища існування, професійного розвитку і самовдосконалення, рівня фізичного здоров'я тощо [13, 16, 22].

Однією 3 найважливіших проблем сучасних юнаків і дівчат $є$ проблема спілкування із своїми ровесниками, оскільки саме ці стосунки є визначальними у житті підлітка, формують його поведінку, навчальну і трудову діяльність, а в майбутньому формують соціальні установки і особливості особистості $[8,14]$. Важливим для учнів та студентів є можливість зайняти важливе місце серед колективу, мати визнання чи лідерські позиції в своєму оточенні. Однак, не кожен підліток може досягати такого статусу, тому що індивідуальні особливості акцентуйованих рис характеру та різноманітні соціальні обмеження переважної більшості юнаків перешкоджають соціалізуватися саме в тому соціальному середовищі, яке $\epsilon$ бажаним $[17,19]$. Досить часто дана ситуація зумовлена тим, що підлітки не можуть адекватно себе оцінити, сприйняти індивідуальні особливості характеру, і тому не можуть віднайти для себе адекватне референтне середовище спілкування та самоствердження. Завдяки вищесказаному, вивчення впливу акцентуації характеру на рівень статусної ієрархії в колективі набуває нового значення та актуальності у практичній діяльності психологів, викладачів та медичних працівників.

Юнаки та дівчата 3 нестійкою акцентуацією характеру мають потребу у постійному контролі за собою, високій вимогливості, дисципліні. Тому, у сприятливому середовищі існування, де прикладом для них $є$ лідери позитивного характеру мислення та вчинків, а норми поведінки в колективі не суперечать загальноприйнятим моральним принципам, підлітки з нестійким рівнем акцентуації будуть мало чим відрізнятися від усіх інших [3]. При таких сприятливих умовах та допомозі і вчасному контролю з боку батьків вони можуть навчатися на рівні середніх показників, а також їх поведінка не буде виходити за межі морально дозволених принципів. Для юнаків і дівчат, які потраплять у позитивний трудовий колектив, у якому будуть мати місце соціально спрямовані стереотипи поведінки, створять сім'ю з половинкою, яка буде мати лідерські якості та позитивне мислення, то майбутнє такого індивідуума складеться повністю благополучно [5].

Мета статті: показати особливості впливу акцентуації характеру на основні характеристики поведінки учнів та студентів сучасних навчальних закладів різних типів.

Матеріали і методи. Під час вивчення акцентуації характеру серед учнів та студентів, які перебувають в умовах сучасних освітніх закладів у контексті стресостійкості, проводили їх обстеження у п'ятьох сучасних закладах освіти м. Івано-Франківська: Прикарпатський національний університет імені Василя Стефаника, Івано-Франківський фінансово-комерційний кооперативний коледж імені С. Граната, Івано-Франківське музичне училище імені Дениса Січинського, Івано-Франківський професійний ліцей автомобільного транспорту і будівництва №15, Івано-Франківський ліцей-інтернат для обдарованих дітей з сільської місцевості. У ході роботи проведено обстеження 300 учнів та студентів (в тому числі 150 дівчат та 150 юнаків).

Для оцінки акцентуацій характеру використовували опитувальник Шмішека. Це особистісний опитувальник, створений для діагностики типу акцентуації особистості та $€$ методом впровадження типологічного підходу вивчення іiі впливу. Методика включає в себе 88 запитань, на які необхідно відповісти «так» чи «ні». Використовуючи дану методику, визначають наступні 10 типів акцентуації характеру особистості:

Циклотимний тип. Визначається частими змінами настрою, а також високим рівнем впливу на особу оточуючої ситуації. Позитивні події провокують бажання діяти, підвищення говірливості, комунікабельності; негативні - пригнічення, недоброзичливість, замкнутість у власній особі, схильність до депресії, можливі навіть суїцидальні спроби.

Демонстративний тип. Визначається завищеним рівнем самооцінки, демонстративністю поведінкових реакцій, легким налагодженням контактів 3 оточуючими. Мають підвищену схильність до фантазерства, люблять прикидатися, прикрашати власної особистість, схильні до артистизму. Прагнуть до лідерства, визнання, похвали, вимагають захоплення, хочуть займати особливе місце, здатні до неординарного мислення й вчинків.

Збудливий тип. Визначається високим рівнем імпульсивності, дратівливості, запальності. Часто провокують конфлікти, неохоче навчаються і працюють, не переймаються 
майбутнім, живуть сьогоденням, намагаються взяти від життя якнайбільше розваг, можуть бути владним у колективі слабших.

Дистимний тип. Визначається серйозністю, розважливістю, відсутністю вольових зусиль, заниженою самооцінкою, небагатослівністю, Уникають веселих компаній, цінують друзів, дуже сумлінні, мають загострене відчуття справедливості.

Екзальтований тип. Визначається високим рівнем контактності, закоханістю, вмінням захоплюватися. Дуже часто вступають в суперечки, але не допускають конфліктів, вірні, альтруїстичні, здатні співчувати, володіють естетичним смаком, щиро виявляють почуття, легко змінюють настрій, поривчасті, швидко переходять від захоплення до розчарування.

Гіпертимний тип. Визначається високим рівнем рухливості, товариськістю, інтенсивною жестикуляцією та мімікою, пустотливістю. Добре почуваються в компанії, прагнуть лідерства, миють завищену самооцінку, веселі, легковажні, життєрадісні, ініціативні, діяльні, винахідливі. Тяжко переживають жорстоку дисципліну, не люблять монотонну роботу, самотність.

Застрягаючий тип. Визначається товариськістю, нестримним бажанням до повчань, мовчазністю, недовірливістю, обережністю, чутливістю до образ, швидкою засмучуваністю, шанолюбством. Ставлять за мету досягти високих показників у всіх своїх справах, наполегливі та цілеспрямовані, у відносинах ревниві, образливі та мстиві.

Емотивний тип. Визначається емоційністю, чутливістю, тривожністю, балакучістю, бридливістю. Мають виражено розвинене почуття гуманності та співчуття. Вразливі, дуже близько сприймають життєві події, неконфліктні, приховують образи, емоції. Мають яскраво виражене почуття обов'язку, самокритичні.

Педантичний тип. Визначається ригідністю, інертністю, не конфліктністю, не мають лідерських якостей. Пунктуальні, акуратні, дуже люблять чистоту та порядок, скрурпульозні, сумлінні, завжди суворо дотримуються правил, неквапливі у роботі, посидючі, схильні до самоперевірок та сумнівів.

Тривожний тип. Визначається сором'язливістю, невпевненістю у собі. Воліють уникати веселих товариств та різних ігор, дуже хвилюються через контрольні, екзамени, перевірки. Мають високий рівень відповідальності, моральні та етичні вимоги. Стверджуються у тих видах діяльності, де вдається показати свої здібності, товариські, самокритичні.

Усі перелічені якості характеру юнаків та дівчат в основному залежать від сімейних цінностей та виховання. Батьки та інші члени сім'ї активно впливають на самооцінку i самоповагу, дотримання соціально прийнятних норм і правил. Про вплив тих чи інших подій та ситуацій дітям теж розповідають батьки. Підтримка і розуміння з боку сім'ї теж допомагає дітям мати більшу популярністю в колі ровесників та відчувати себе більш впевнено і органічно.

Результати досліджень. Під час дослідження ступеня прояву АХ за гіпертимним типом, встановлено їх наступні значення: $17,13 \pm 0,65$ бали у юнаків та $16,97 \pm 0,61$ балів $(2,3 \% ; \mathrm{p}(\mathrm{t}) \mathrm{yH}>0,05)$ у дівчат університету, $16,87 \pm 1,07$ балів у юнаків та $17,33 \pm 1,02$ балів $(2,1 \%$; $\mathrm{p}(\mathrm{t})$ л $>0,05)$ у дівчат ліцею, $16,53 \pm 0,75$ балів у юнаків та $16,83 \pm 0,70$ балів $(3,0 \% ; \mathrm{p}(\mathrm{t}) \mathrm{y}>0,05)$ у дівчат училища, $16,70 \pm 0,92$ балів у юнаків та $17,30 \pm 0,99$ балів $(3,3 \% ; \mathrm{p}(\mathrm{t}) \mathrm{\kappa}>0,05)$ у дівчат коледжу, а також $15,87 \pm 0,72$ балів у юнаків та $17,00 \pm 0,89$ балів $(3,5 \%$; $\mathrm{p}(\mathrm{t}) ш>0,05)$ у дівчат школи.

Стосовно проявів $\mathrm{AX}$ за застрягаючим типом, то виявлено такі його значення: $12,93 \pm 0,54$ бали у юнаків та $13,47 \pm 0,44$ балів $(1,8 \%$; $\mathrm{p}(\mathrm{t}) \mathrm{yH}>0,05)$ у дівчат університету, $12,57 \pm 0,57$ балів у юнаків та $13,40 \pm 0,52$ балів $(2,4 \% ; \mathrm{p}(\mathrm{t}) \pi>0,05)$ у дівчат ліцею, $12,67 \pm 0,53$ балів у юнаків та $13,43 \pm 0,39$ балів $(1,3 \%$; $\mathrm{p}(\mathrm{t}) \mathrm{yч}>0,05)$ у дівчат училища, $13,07 \pm 0,54$ балів у юнаків та $13,40 \pm 0,47$ балів $(1,6 \% ; \mathrm{p}(\mathrm{t}) \kappa>0,05)$ у дівчат коледжу, а також $13,13 \pm 0,55$ балів у юнаків та $13,53 \pm 0,44$ балів $(1,5 \% ; \mathrm{p}(\mathrm{t}) ш>0,05)$ у дівчат школи.

Показники рівня проявів зациклювання особистості за емотивним типом, мали значення, величини яких становили $13,00 \pm 0,44$ бали у юнаків та $15,90 \pm 0,55$ балів $(1,6 \% ; \mathrm{p}(\mathrm{t}) \mathrm{yH}>0,05)$ у дівчат університету, $11,83 \pm 0,48$ балів у юнаків та $15,53 \pm 0,66$ балів $(1,6 \% ; \mathrm{p}(\mathrm{t}) \pi>0,05)$ у дівчат ліцею, $12,30 \pm 0,44$ балів у юнаків та $15,60 \pm 0,63$ балів $(1,4 \%$; $\mathrm{p}(\mathrm{t}) \mathrm{yч}>0,05)$ у дівчат училища, $12,23 \pm 0,65$ балів у юнаків та $15,57 \pm 0,57$ балів $(1,2 \% ; \mathrm{p}(\mathrm{t}) \kappa>0,05)$ у дівчат коледжу, а також $12,73 \pm 0,55$ балів у юнаків та $15,53 \pm 0,55$ балів $(1,1 \%$; $\mathrm{p}(\mathrm{t}) ш>0,05)$ у дівчат школи.

Показники величини AX за педантичним типом, мають наступні значення: $12,17 \pm 0,40$ бали у юнаків та $12,70 \pm 0,38$ балів $(1,3 \%$; $\mathrm{p}(\mathrm{t}) \mathrm{yH}>0,05)$ у дівчат університету, $11,40 \pm 0,58$ балів у юнаків та $11,70 \pm 0,50$ балів $(1,2 \% ; \mathrm{p}(\mathrm{t}) л>0,05)$ у дівчат ліцею, $11,97 \pm 0,43$ балів у юнаків та $11,77 \pm 0,35$ балів $(1,1 \% ; \mathrm{p}(\mathrm{t}) \mathrm{y}>0,05)$ у дівчат училища, $11,00 \pm 0,43$ балів у юнаків та $11,63 \pm 0,43$ балів $(1,3 \%$; $\mathrm{p}(\mathrm{t}) \kappa>0,05)$ у дівчат коледжу, а також $11,57 \pm 0,39$ балів у юнаків та $12,00 \pm 0,43$ балів $(1,4 \%$; $\mathrm{p}(\mathrm{t}) ш>0,05)$ у дівчат школи. 
Значення величин рівня прояву акцентуйованих характерних рис особливостей особистості за тривожним типом, становили $11,03 \pm 0,31$ бали у юнаків та $12,67 \pm 0,32$ балів $(1,3 \%$; $\mathrm{p}(\mathrm{t}) \mathrm{yн}>0,05)$ у дівчат університету, $10,53 \pm 0,46$ балів у юнаків та $12,30 \pm 0,36$ балів $(1,7 \%$; $\mathrm{p}(\mathrm{t}) \mathrm{\Omega}>0,05)$ у дівчат ліцею, $10,60 \pm 0,34$ балів у юнаків та $12,53 \pm 0,28$ балів $(1,1 \%$; $\mathrm{p}(\mathrm{t}) \mathrm{y} ч>0,05)$ у дівчат училища, $10,01 \pm 0,40$ балів у юнаків та $12,47 \pm 0,27$ балів $(1,5 \% ; \mathrm{p}(\mathrm{t}) \mathrm{\kappa}>0,05)$ у дівчат коледжу, а також $10,80 \pm 0,40$ балів у юнаків та $12,10 \pm 0,28$ балів $(1,4 \%$; $\mathrm{p}(\mathrm{t}) ш>0,05)$ у дівчат школи (рис. 1$)$.

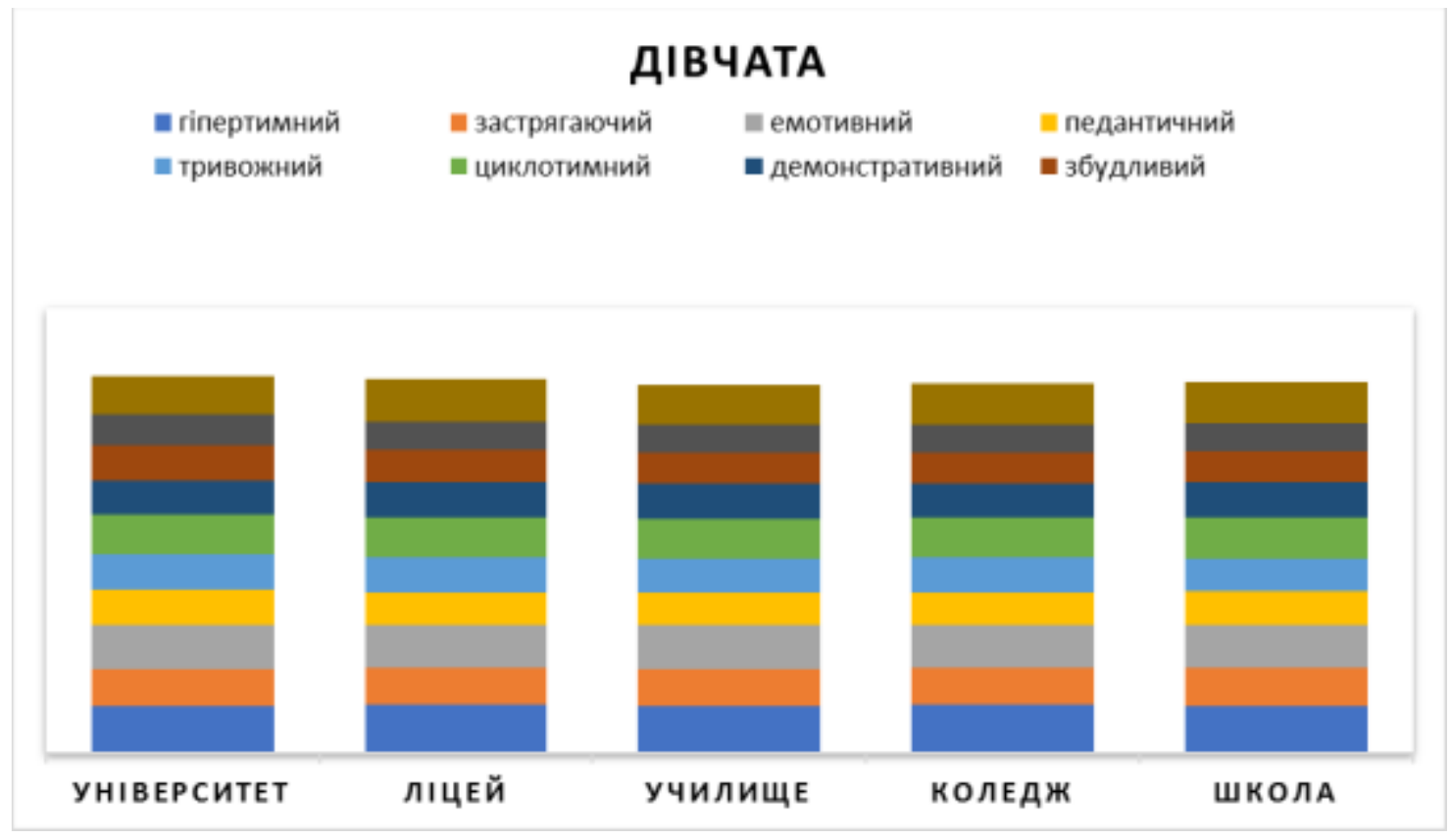

Рис. 1 Основні величини показників типів АХ юнаків сучасних закладів освіти різних типів за даними особистісного опитувальника Шмішека, дівчата

Оцінюючи закономірності змін величин прояву показників $\mathrm{AX}$ за циклотимним типом, їх показники складали $13,03 \pm 0,43$ бали у юнаків та $13,83 \pm 0,51$ балів $(1,4 \%$; $p(t) y н>0,05)$ у дівчат університету, $12,53 \pm 0,70$ балів у юнаків та $14,47 \pm 0,70$ балів $(1,1 \% ; \mathrm{p}(\mathrm{t})$ л $>0,05)$ у дівчат ліцею, $13,30 \pm 0,47$ балів у юнаків та $14,03 \pm 0,47$ балів $(1,4 \%$; $\mathrm{p}(\mathrm{t}) \mathrm{yч}>0,05)$ у дівчат училища, $12,37 \pm 0,55$ балів у юнаків та $14,23 \pm 0,50$ балів $(1,6 \% ; \mathrm{p}(\mathrm{t}) \mathrm{k}>0,05)$ у дівчат коледжу, а також $12,77 \pm 0,51$ балів у юнаків та $14,37 \pm 0,47$ балів $(1,2 \% ; \mathrm{p}(\mathrm{t}) ш>0,05)$ у дівчат школи.

Відносно стабільними були основні значення, які відповідали за характерні риси особливості акцентуйованих ознак відповідно до шкали демонстративності і величина прояву величин вираження описаних ознак складала $11,90 \pm 0,37$ бали у юнаків та $12,63 \pm 0,32$ балів $(1,1 \%$; $\mathrm{p}(\mathrm{t}) \mathrm{yн}>0,05)$ у дівчат університету, $11,47 \pm 0,47$ балів у юнаків та $12,43 \pm 0,51$ балів $(1,7 \% ; \mathrm{p}(\mathrm{t})$ л $>0,05)$ у дівчат ліцею, $11,80 \pm 0,40$ балів у юнаків та $12,47 \pm 0,39$ балів $(1,5 \%$; $\mathrm{p}(\mathrm{t}) \mathrm{yч}>0,05)$ у дівчат училища, $11,73 \pm 0,45$ балів у юнаків та $12,23 \pm 0,44$ балів $(1,5 \%$; $\mathrm{p}(\mathrm{t}) \mathrm{k}>0,05)$ у дівчат коледжу, а також $11,77 \pm 0,41$ балів у юнаків та $12,70 \pm 0,39$ балів $(1,4 \% ; \mathrm{p}(\mathrm{t}) ш>0,05)$ у дівчат школи.

Показники результатів оцінювання рівня прояву величин АХ за збудливим типом, відповідно дорівнювали $11,43 \pm 0,40$ бали у юнаків та $12,27 \pm 0,38$ балів $(1,2 \%$; $p(t) y н>0,05)$ у дівчат університету, $10,63 \pm 0,38$ балів у юнаків та $11,67 \pm 0,45$ балів $(1,4 \% ; \mathrm{p}(\mathrm{t}) \pi>0,05)$ у дівчат ліцею, $10,50 \pm 0,41$ балів у юнаків та $11,53 \pm 0,39$ балів $(1,3 \%$; $\mathrm{p}(\mathrm{t}) \mathrm{yч}>0,05)$ у дівчат училища, $10,37 \pm 0,43$ балів у юнаків та $11,17 \pm 0,44$ балів $(1,1 \%$; $\mathrm{p}(\mathrm{t}) \mathrm{k}>0,05)$ у дівчат коледжу, а також $10,33 \pm 0,32$ балів у юнаків та $11,50 \pm 0,47$ балів $(1,5 \% ; \mathrm{p}(\mathrm{t}) ш>0,05)$ у дівчат школи.

У процесі оцінки результатів роботи, а саме рівня прояву величин АХ за дистимним типом виявили, що ступінь прояву цих показників складав $10,50 \pm 0,46$ бали у юнаків та $11,10 \pm 0,38$ балів $(1,4 \% ; \mathrm{p}(\mathrm{t}) \mathrm{yH}>0,05)$ у дівчат університету, $9,30 \pm 0,53$ балів у юнаків та $10,20 \pm 0,55$ балів $(1,6 \%$; $\mathrm{p}(\mathrm{t})$ л $>0,05)$ у дівчат ліцею, $9,80 \pm 0,45$ балів у юнаків та $9,93 \pm 0,51$ балів $(1,2 \%$; $\mathrm{p}(\mathrm{t}) \mathrm{y} ч>0,05)$ у дівчат училища, $9,23 \pm 0,46$ балів у юнаків та $9,83 \pm 0,54$ балів $(1,4 \% ; \mathrm{p}(\mathrm{t}) \mathrm{\kappa}>0,05)$ у дівчат коледжу, а також $9,47 \pm 0,41$ балів у юнаків та $9,93 \pm 0,57$ балів $(1,1 \% ; \mathrm{p}(\mathrm{t}) ш>0,05)$ у дівчат школи (рис. 2$)$. 


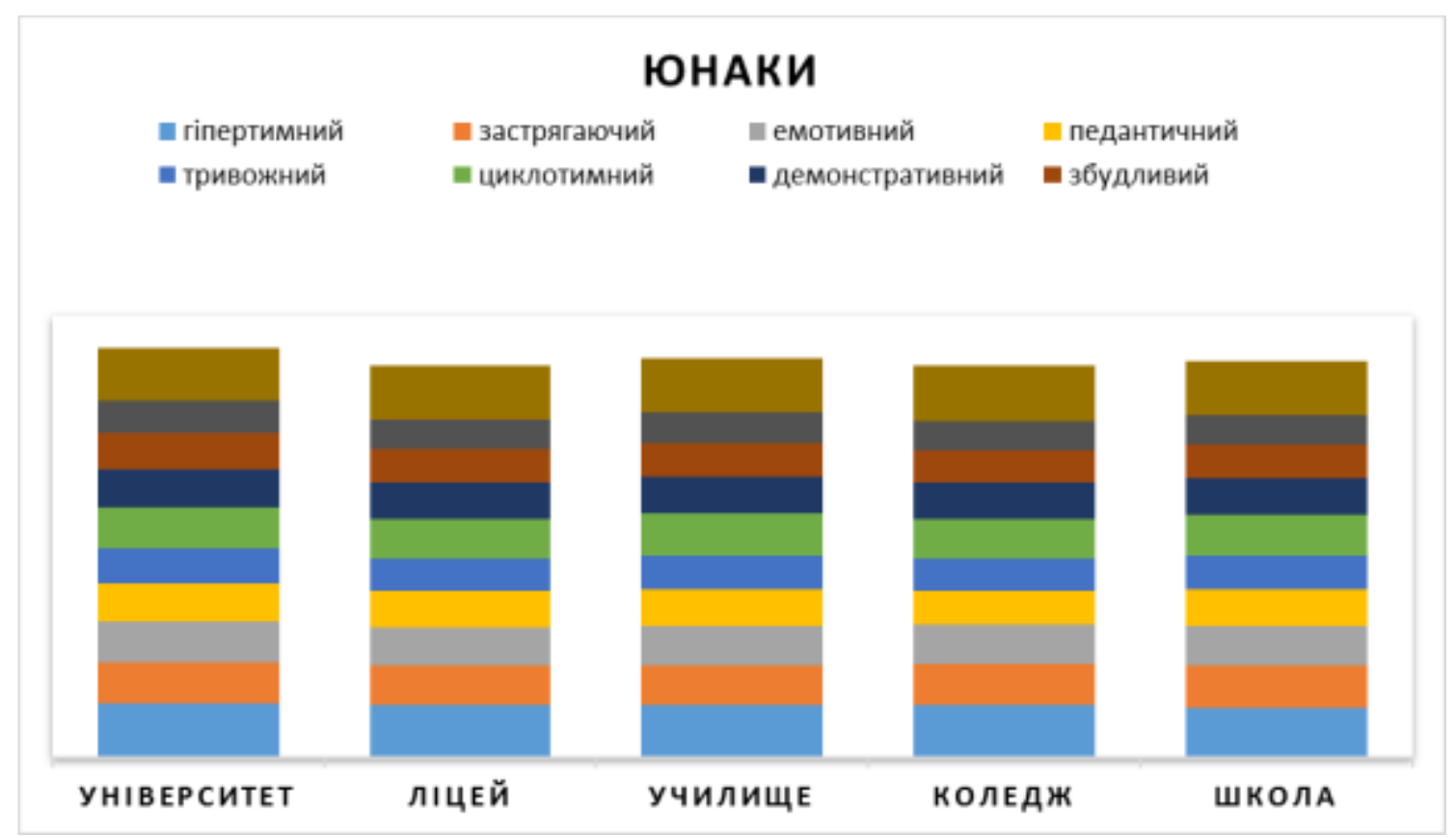

Рис. 2. Основні величини показників типів АХ юнаків сучасних закладів освіти різних типів за даними особистісного опитувальника Шмішека, юнаки

Оцінюючи результати показників рівня прояву особливостей $\mathrm{AX}$ за екзальтованим типом, досліджено, що їх значення становлять $16,47 \pm 0,77$ бали у юнаків та $14,17 \pm 0,62$ балів (1,5\%; $\mathrm{p}(\mathrm{t}) \mathrm{yH}>0,05)$ у дівчат університету, $17,07 \pm 0,87$ балів у юнаків та $15,30 \pm 1,07$ балів $(1,8 \% ; \mathrm{p}(\mathrm{t}) л>0,05)$ у дівчат ліцею, $16,83 \pm 0,79$ балів у юнаків та $14,37 \pm 0,72$ балів $(1,3 \%$; $\mathrm{p}(\mathrm{t}) \mathrm{y} ч>0,05)$ у дівчат училища, $17,23 \pm 0,89$ балів у юнаків та $14,87 \pm 0,87$ балів $(1,5 \%$; $\mathrm{p}(\mathrm{t}) \mathrm{\kappa}>0,05)$ у дівчат коледжу, а також $17,10 \pm 0,84$ балів у юнаків та $14,60 \pm 0,78$ балів $(1,2 \% ; \mathrm{p}(\mathrm{t}) ш>0,05)$ у дівчат школи.

Висновки. 1. Одним з найефективніших методів вивчення міжособистісних стосунків у підлітковому віці $\epsilon$ соціометрія, яка дає можливість зробити висновки про стан міжособистісних стосунків в певному колективі.

2. На появу акцентуацій характеру не ізольовано, а взаємопов'язано впливають соціальні та біологічні фактори, які створюють передумови для формування девіантної поведінки та можуть бути рушійною силою розвитку невротичних реакцій, агресивної поведінки та негативно впливати на можливості самореалізації та соціальної адаптації.

3. Своєчасне виявлення та визначення типу акцентуації характеру в учнів та студентів $\epsilon$ надзвичайно важливим як для профілактики, так і для проведення медичної, педагогічної та соціально-психологічної корекції відповідних відхилень у поведінкових реакціях, емоційних зривів або нервово-психічних порушень.

\section{ЛIТЕРАТУРА}

1. Драгунова Т.В. Психологічні особливості підлітка / Т.В. Драгунова // Вікова і педагогічна психологія / під ред. А.В. ГІетровського М.: Просвещение, 1979. С. 98-141.

2. Запухляк 0.3. Особливості агресії акцентуйованих підлітків / Запухляк 0.3. // Проблеми загальної та педагогічної психології. Збірник наукових праць Інституту психології ім. Г.С. Костюка АПН України. К., 2004, т. VI, вип. 1. С. 152-157.

3. Леонгард К. Акцентуйовані особистості К., Пер. з нім. [Предисл. і ред. Блейхера В.М.] / К. Леонгард 2-е вид. стер. К.: Виш. шк. Головне видавництво, 1989. 375 с.

4. Лічко А.Е. Психопат і акцентуації характеру у підлітків / А.С. Лічко Ленінград: Медицина, 1983. 318 с.

5. Подмазін С.І., Роль установки у формуванні та виявленні акцентуйованих рис характеру у підлітків. - K.: 1994. - c. 18

6. Трус И., Модель социально-педагогического сопровождения подростков с акцентуациями характера // Воспитание школьников. - 2003. - №3. - С. 26-32

7. Фадеева Е.В., Типологический анализ акцентуаций характера. Графические методы, как способ диагностики акцентуаций характера// Коррекционная педагогика. - 2006. - №4. - С. 17-27

8. Шамшурин А.Г., Проблемы интерпретации результатов диагностики акцентуации характера по методике Шмишека//Практична психологія та соціальна робота. - 2002. - №4. - С. 54-58 
9. Antonio, A. L. "Diversity and the Influence of Friendship Groups in College." Review of Higher Education, 2001, 25(1), 63-89.

10. Astin, A. W., Sax, L. J., and Avalos, J. "Long-Term Effects of Volunteerism During the Undergraduate Years." Review of Higher Education, 1999, 22(2), 187-202.

11. Horowitz, H. L. Campus Life: Undergraduate Cultures from the End of the Eighteenth Century to the Present. Chicago: University of Chicago Press, 1987.

1. Jacob, P. Changing Values in College: An Exploratory Study of the Impact of College Teaching. New York: HarperCollins, 1957.

12. Kuh, G. D. "The Other Curriculum: Out-of-Class Experiences Associated with Student Learning and Personal Development." Journal of Higher Education, 1995, 66(2), 123-155.

13. Kuh, G. D. "Assessing What Really Matters to Student Learning: Inside the National Survey of Student Engagement." Change, 2001, 33(3), 10-17, 66.

14. Milem, J. F., and Hakuta, K. "The Benefits of Racial and Ethnic Diversity in Higher Education." In D. Wilds (ed.), Minorities in Higher Education: Seventeenth Annual Status Report. Washington, D.C.: American Council on Education, 2000.

15. National Survey of Student Engagement. From Promise to Progress: How Colleges and Universities Are Using Student Engagement Results to Improve Collegiate Quality. Bloomington: Center for Postsecondary Research, Indiana University, 2002.

16. Parks, S. D. Big Questions, Worthy Dreams: Mentoring Young Adults and the Search for Meaning, Faith, and Commitment. San Francisco: Jossey-Bass, 2000.

17. Pascarella, E. T. "Using Student Self-Reported Gains to Estimate College Impact: A Cautionary Tale." Journal of College Student Development, 2001, 42(5), 488-492.

18. Pascarella, E. T., and Terenzini, P. T. How College Affects Students: Findings and Insights from Twenty Years of Research. San Francisco: Jossey-Bass, 1991.

19. Pike, G. R. "Limitations of Using Students' Self-Reports of Academic Development as Proxies for Traditional Achievement Measures." Paper presented at the annual meeting of the Association for Institutional Research, Boston, 1995.

20. Pike, G. R. "The Constant Error of the Halo in Educational Outcomes Research." Research in Higher Education, 1999, 40(1), 61-86.

21. Pohlmann, J. T. "A Description of Effective College Teaching in Five Disciplines as Measured by Student Ratings." Research in Higher Education, 1974, 4(4), 335- 346.

22. Rudolph, F. The American College and University: A History. Athens: University of Georgia Press, 1990.

23. Umbach, P., and Kuh, G. D. "Student Experiences with Diversity at Liberal Arts Colleges: Another Claim for Distinctiveness." Paper presented at the annual meeting of the Association for Institutional Research, Tampa, 2003. 